\title{
New evidence of the Neolithic period in West Central Zagros: the Sarfirouzabad-Mahidasht Region, Iran
}

\author{
Kamal-Aldin Niknami and Meisam Nikzad \\ Department of Archaeology, Tehran University, IR \\ Kniknami@ut.ac.ir; Meisam_Nikzad@yahoo.com
}

\begin{abstract}
Because the eastern region of the Mahidasht Valley in the Sarfirouzabad region, to the south-east of Kermanshah Province, had not been studied by archaeologists, this area of central Zagros was surveyed in 2009 by a team from Tehran University. We identified 17 sites dating to the Neolithic period. The finds indicate that the formation of sedentary societies began in the pre-pottery Neolithic in this area and was followed by a considerable increase in the number of sites during the pottery Neolithic period. Preliminary analyses of these sites will be presented in the present article.

IZVLEČEK - V vzhodnen delu doline Mahidasht v regiji Sarfirouzabad, jugovzhodno od province Kermanshah arheoloških raziskav še ni bilo, zato je to območje v centralnem Zagrosu s terenskimi pregledi leta 2009 raziskala arheološka skupina iz Univerze v Teheranu. Prepoznali smo 17 najdǐ̌č iz neolitskega obdobja. Najdbe kažejo, da se je oblikovanje družb s stalno poselitvijo na tem območju začelo že v obdobju pred-keramičnega neolitika, ki mu je sledilo občutno povečanje števila najdišč v obdobju keramičnega neolitika. V tem članku predstavljamo preliminarne analize teh najdišč.
\end{abstract}

KEY WORDS - archaeological survey; Neolithic settlement; Sarfirouzabad; central Zagros

\section{Introduction}

As a result of the increasing number of archaeological studies in the 1960s and 1970s, and following Robert J. Braidwood's excavations (Braidwood 1960a; 1960b; 1961; Braidwood et. al. 1961), the central Zagros area of Iran was identified as a key region with great potential for studying the process of Neolithisation in the Near East. After Braidwood, other areas of central Zagros, including Hulailan (Meldgard et al. 1963; Mortensen 1972; 1974), Lurestan (Goff 1971; Young 1966; Hole, Flannery 1967; Pullar 1990), Mahidasht (Levine 1974; Levine, McDonald 1977), the Kermanshah suburbs (Smith 1976; 1990; Smith, Mortensen 1980), and Kangavar (Young 1969; 1975) were also investigated and excavated by archaeologists from different countries; this period of research is called the Golden Age (Wilkinson 2000). With the Islamic revolution in Iran, Neolithic studies came to a halt. Although laboratory and field studies have recently re- commenced (Zeder 2005; Matthews et al. 2010; Darabi et al. 2011), the lack of research caused a change in the views of researchers about the status of studies of central Zagros in the process of the Near Eastern Neolithisation (Hole 1999). One of the complicating factors in researching the Neolithic in this region, compared to areas like the Levant, is the inadequacy of identified and excavated sites, which has led to the assumption that some parts of the region were abandoned and deserted (McDonald 1979; Hole 1987).

Therefore, the identification of a considerable number of Neolithic sites in the Sarfirouzabad area in the 2009 survey will greatly enhance our knowledge about central Zagros in the Neolithic period.

Meanwhile, new excavations and recent studies point to the significance of the Zagros area and its valleys 
as one of the earliest focuses of plants and animals domestication (Matthews et al. 2010; Nikzad 2011; Darabi et al. 2011).

\section{Geographical setting}

Sarfirouzabad is located $30 \mathrm{~km}$ westsouthwest of Kermanshah and measures $971 \mathrm{~km}^{2}$ in area (Fig. 1). Geographically, Sarfirouzabad is the natural continuation of the Mahidasht plain, which is located to the south-southeast; the southern part is bounded by the Saimareh River and Luristan Province. Sarfirouzabad is a large compound syncline surrounded by two mountainous southwestern and northeastern chains. The northeastern chain includes Mts. Khowra-tav and Sefid, while the southwestern mountains are lower and include the Nesar, Kaleh Mol, and Lal-abad mountains. Another natural morphological feature of the plain is the Mereg River, which is a tributary of Iran's third long river, the Karkheh. The region is considered to have a rich environment and has abundant water resources, chert outcrops, and abundant forests and pasture.

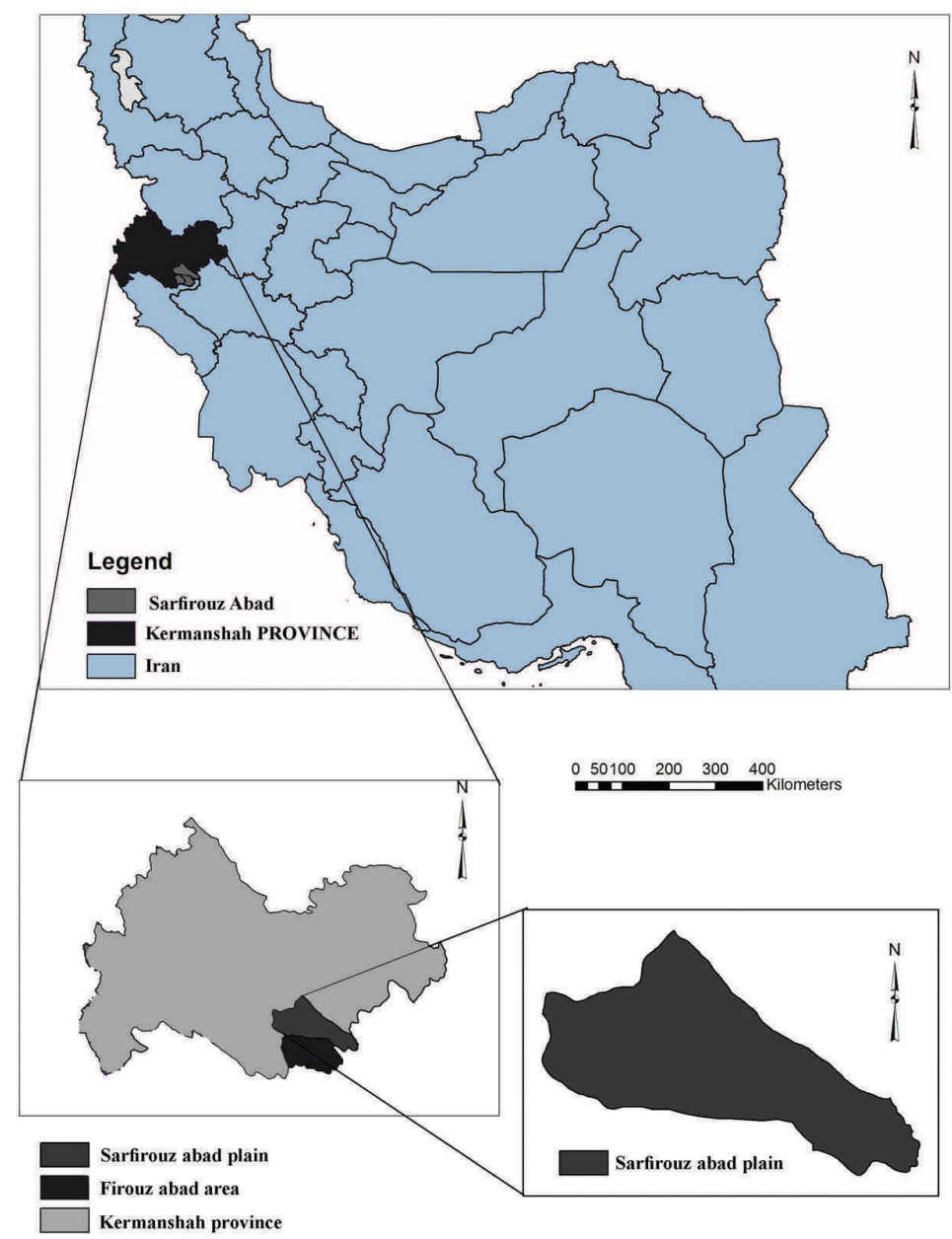

Fig. 1. Map of the Sarfirouzabad area.

\section{Archaeological studies in Sarfirouzabad}

Despite the fact that Sarfirouzabad shares a border with Mahidasht, its archaeological research is less well-known. Until the 2009 survey, only two expeditions had been able to conduct a limited survey in the Sarfirouzabad area. During the first, between 1963-1967 when Clare Goff was investigating Pishkoh district in Luristan, she was able to visit Sarfirouzabad (south-east of Mahidasht) and recorded a few sites (Goff 1971). But she never published data on the number or chronology of the sites she identified.

Later, during the Mahidasht project, Louise Levine was able to visit some parts of the Sarfirouzabad area ( $L e$ vine 1974; 1975; Levine, McDonald 1977), although Levine never referred to any recognised sites in the area. However, Mary A. McDonald bad plain. mentioned in her $\mathrm{PhD}$ thesis that there were three sites with pottery Neolithic remains in Sarfirouzabad (McDonald 1979.552).

\section{The 2009 survey}

In 2009 a team supervised by Kamal-Aldin Niknami conducted an intensive field survey of the Sarfirou-

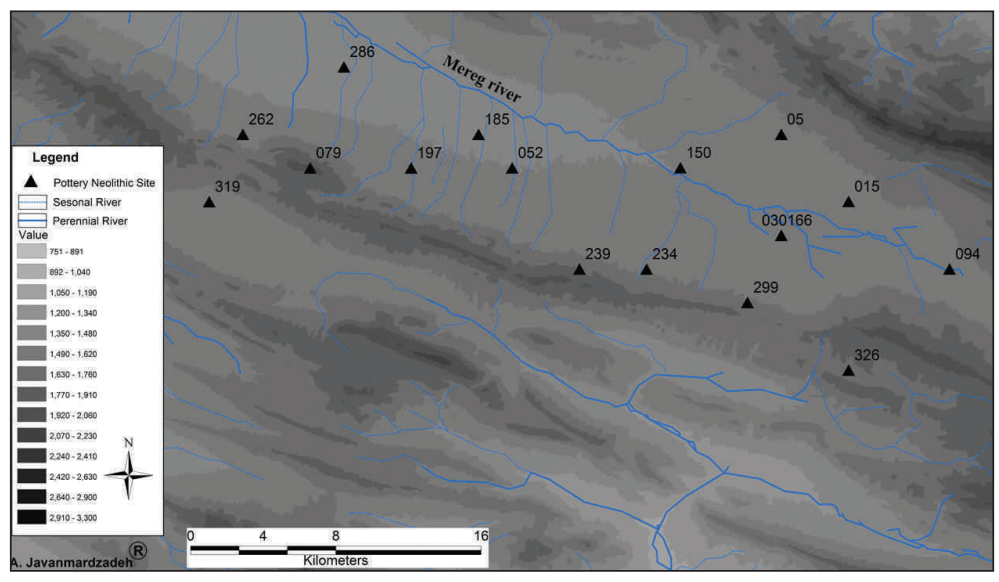

Fig. 2. Map of the distribution of Neolithic sites on the Sarfirouza- 


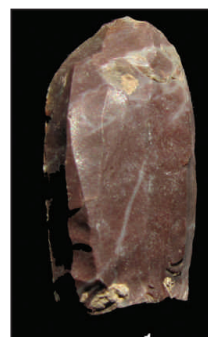

1

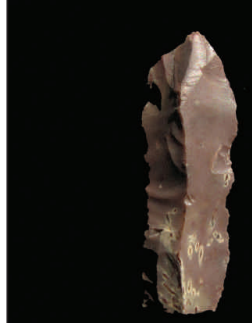

6

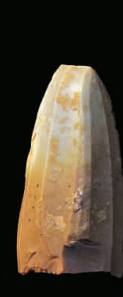

2

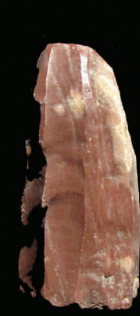

3

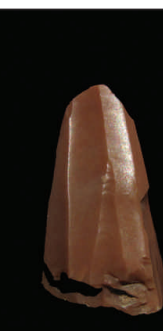

4
5

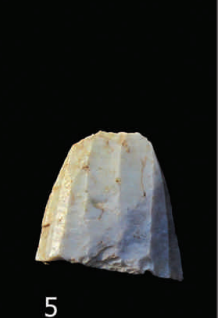

with a number of ecological niches and special food resources during particular seasons of the year.

The proximity of food resources such as game animals, grains, acorn, and other nuts and fruits, and also easy access to springs and the food security required for wild goat herds throughout the year were probably among the factors in the border valleys that attracted the first sedentary societies on the Sarfirouzabad plain, or in other words, in Mahidasht. Pre-pottery Neolithic sites are located at $1509 \mathrm{~m}$ a.s.l., and all three sites are located at a distance of $250 \mathrm{~m}$ from reliable water sources; the sites cover less than one hectare each and are located in places

Fig. 3. Pre-pottery Neolithic stone artefacts from Chia Chakhmagho.

zabad region over a period of 60 days (Niknami 2010). The survey, which consisted solely of fieldwalking, covered all areas suitable for settlement, including agricultural flatlands, the terraces of the Mereg River and the hillocks on the border of the plain. During the survey, 332 sites from the Palaeolithic to late the Islamic period were identified, including 17 settlements with remains attributable to the Neolithic period (Fig 2).

\section{Neolithic settlements}

According to the surface finds study, three sites Chia chakhmagho (SF.5), Banbavani 1 (SF.166) and Chelleh Olia 1 (SF.286) - yielded remains from the pre-pottery Neolithic. The significance of these sites lies in the fact that sites of this age have never been reported from previous research at Mahidasht (Braidwood 1960a; 1960b; 1961; Levine 1974; 1975). Brookes et al. believe that the absence of such sites was due to geological phenomena and extreme sedimentation in Mahidasht, which perhaps buried the early sites (Brookes et al. 1982). However, Phillip E. L. Smith and Cuyler T. Young (1983) note that settlements of this age should not be sought on wide, open plains, but in narrow and open river valleys, since such valleys are considered attractive and significant to early Neolithic societies in terms of providing food security for both people and livestock. They also mention that river valleys provided hunter-gatherer societies which benefit from various niches. Surface finds from these sites include a bullet-shape core, a backed and sided blade, a sickle blade, micro-blades, a scraper and end scraper, flakes, a blade core and flake core, a discoidal flake core and an amorphous flak core (Figs. 3 and 4).

However, Neolithic pottery remains were collected from 15 sites; 14 of these were settlements. In fact, the only site which had both pre-pottery and pottery Neolithic remains was the Chia chakhmagho mound (SF 015). These settlements are located from $1476 \mathrm{~m}$ a.s.l. (Ghomesh Dar Amroo S.F 52) to $1647 \mathrm{~m}$ a.s.l. (Dom-e khor khor S.F 319), of which 4 are located in the northern basin and 11 in the southern basin of the Mereg.

Most of the Neolithic settlements were formed on the first hillock of the southern edge. The water sour-

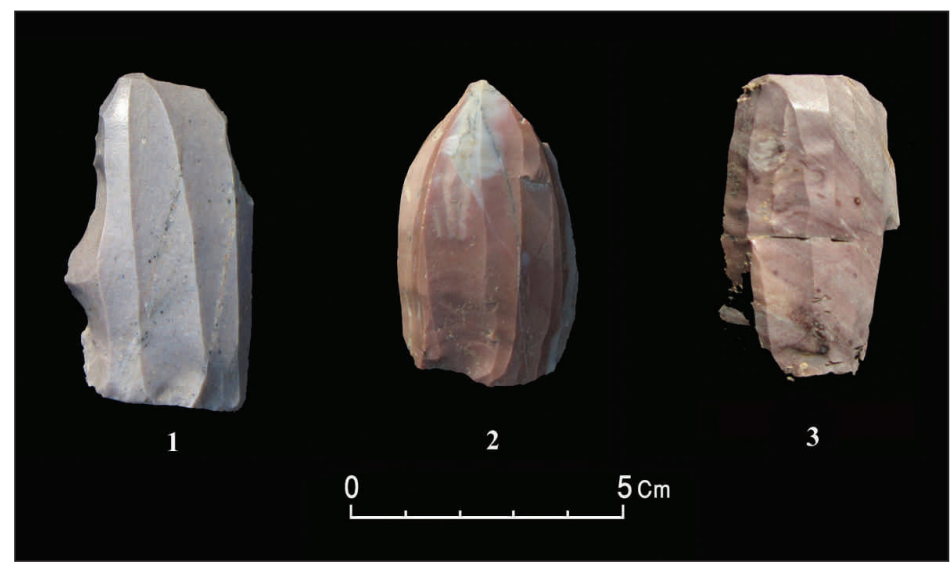

Fig. 4. Pre-pottery Neolithic stone artefacts from Ban Bavani. 
ces of most settlements (10) consisted of streams and seasonal drainages of the Mereg, most of which are located at distances less than $250 \mathrm{~m}$ from the sites. The sites of this period include settlements and seasonal sites. Some settlements were probably used seasonally and for purposes such as hunting, fishing, and grazing etc. given the lack of cultural deposits, distance to water, and proximity to hillocks and pastures, and the scarcity and simplicity of the pottery finds. In conclusion, in the pottery Neolithic of Sarfirouzabad plain settlements with

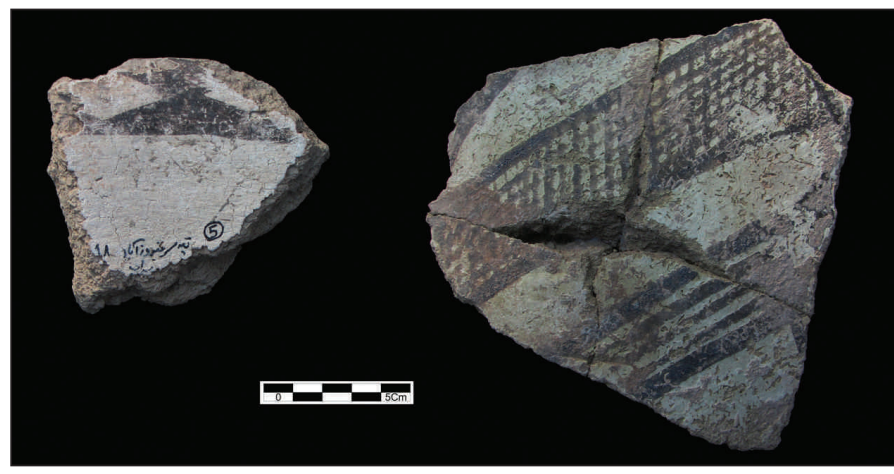

Fig. 5. A sample of Neolithic painted pottery (geometric Sarab style) from Tape Sarab-e Sarfirouzabad. areas of approximately 1-2ha were concentrated in the southern basin of the Mereg River and the north side of Mt. Nesar. The reason for the centralisation of these settlements in the southern basin must be sought in the environmental richness of this area. Factors such as abundant drainages of the Mereg outcrop chert and flatter lands and forest are among the attractions and factors in the formation of pottery settlements in the southern basin of the plain. Most surface settlements on these sites yielded coarse, plain, buff, hand-made, chaff tempered and basic forms of pottery (Fig. 6).

Only a small quantity of painted pottery distinctive of the central Zagros Neolithic - relating to Sarab linear and geometric pottery - was obtained from Tape Sarab Sarfirouzabad (SF095) (Fig. 5).

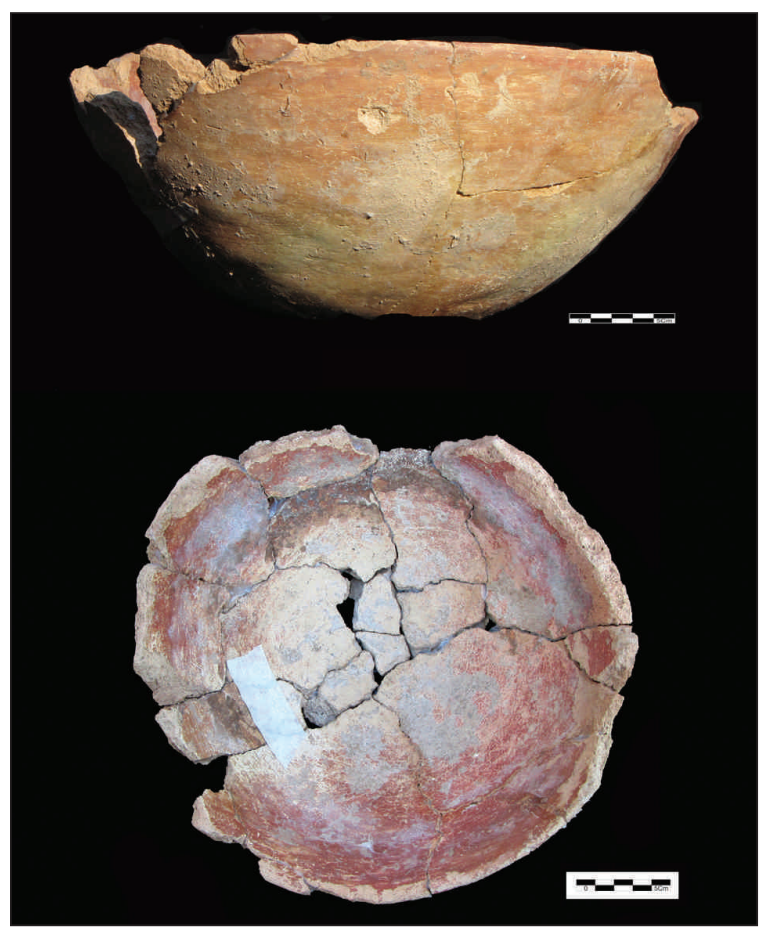

Fig. 6. A sample of plain pottery from Tape Sarab Sarfirouzabad.

\section{Conclusion}

The results of the survey in 2009 showed that Neolithic sites are merely identified by field-walking surveys, since these settlements are located in areas remote from accessible paths and modern villages, and the absence or scarcity of sites identified is not due to their actual absence, but to approaches taken in field surveys. According to the surface finds and settlement patterns, environmental variables play an important role in locating settlements, as we expected. Settlement patterns show that in the pre-pottery Neolithic period hunting was still very important, while agriculture was probably not the basis of subsistence.

Generally, pottery Neolithic settlements in Sarfirouzabad were based on animal husbandry, hunting, and dry farming and were very dependent on natural resources near rivers and mountainsides; in regard to the location and dispersal of sites and surface finds we can observe the following characteristics: (i) the presence of permanent and semi-permanent settlements with a mixed economy with the evident prevalence of livestock and husbandry; (ii) an increasing tendency of patterning in adopting sedentism; (iii) sufficient knowledge from environmental variables; (iv) relative superiority of a herding economy.

\section{ACKNOWLEDGEMENTS}

Appreciation is offered to the Iran National Science Foundation (INSF) for a grant to collect site data which were used for this research. The authors would like to thanks all the members of the survey team for their kindly cooperation and A. Javanmardzadeh and $S$. Alibeigi for providing the map of the region and comments. Grateful thanks to the Cultural Heritage Organization of Kermanshah that provided access to site locations. 


\section{References}

Braidwood R. J. 1960a. Seeking the World's First Farmers in Persian Kurdistan: a Full Scale Investigation of Prehistoric Sites Near Kermanshah. Illustrated London news 237: 695-697.

1960b. Preliminary Investigations Concerning the Origins of Food-Production in Iranian Kurdistan. British Association for the Advancement of Science 17: 214218.

1961. The Iranian Prehistoric Project, 1959-1960. Iranica Antiqua 1: 3-7.

Braidwood R. J., Howe B. and Reed C. A. 1961. The Iranian Prehistoric project. Science 133: 2008-2010.

Brookes I., Levine L. and Denell R. 1982. Alluvial sequence in central west Iran and implications for archaeological survey. Journal of field archaeology 9(3): 285-299.

Darabi H., Naseri R., Young R. and Fazeli H. 2011. The absolute chronology of East chia sabz: a pre-pottery Neolithic site in western Iran. In M. Budja (ed.), 18th Neolithic Seminar. Documenta praehistorica 38: 255-365.

Goff C. 1971. Luristan before the Iron Age. Iran 9: 131-152.

Hole F. 1987. Archaeology of the Village Period. In F. Hole (ed.), The Archaeology of Western Iran: Settlement and Society from Prehistory to the Islamic Conquest. Smithsonian Institution Press, Washington DC: 29-78.

1999. Revisiting the Neolithic. In A. Alizadeh, Y. Majidzadeh and S. Malekshahmirzadi (eds.), The Iranian world, Essay on Iranian art and Archaeology. Iran University press, Tehran: 13-28.

Hole F., Flannery K. V. 1967. The prehistory of southwestern Iran: A preliminary report. Proceedings of the Prehistoric Society 33: 147-206.

Levine L. D. 1974. Archaeological investigations in the Mahidasht, western Iran. Paléorient 2: 487-490.

1975. Survey in the province of Kermanshah, 1975 Mahidasht in the prehistoric and early historic periods. In F. Bagherzadeh (ed.), Proceedings of the IVth annual symposium archaeological research in Iran. Iranian Centre for Archaeological Research, Tehran: 284-297.

Levine L. D., Mcdonald M. A. 1977. The Neolithic and Chalcolithic periods in the Mahidasht. Iran 15: 39-50.

Matthews R., Mohammadi Far Y., Matthews W. and Motarjem A. 2010. Investigating the early Neolithic of west- ern Iran: The central Zagros archaeological project (CZAP). Antiquity 84(323). Project Gallery. Online (http://antiqui ty.ac.uk/projgall/matthews323/).

McDonald M. A. 1979. An examination of Mid-Holocene settlement patterns in the central Zagros region of western Iran. Unpublished PhD thesis. Department of Anthropology, University of Toronto. Toronto.

Meldgaard J., Mortensen P. and Thrane H. 1963. Excavation at tepe Guran, Luristan. Acta Archaeologica 34: 97133.

Mortensen P. 1972. Seasonal Camps and Early Villages in the Zagros. In P. Ucko, R. Tingham and G. W. Dimbleby (eds.), Man, Settlement and Urbanism. Duckworth London.

Mortensen P. 1974. A survey of prehistoric settlements in northern Luristan. Acta Archaelogica 45: 1-47.

Niknami K. A. 2010. The report of Archaeological survey of srafirouz Abad plain. Unpublished report, prepared for Archive of the CHHTO. Iranian Centre for Archaeological Research. Tehran.

Nikzad M. 2011. A survey of the Neolithic settlement patterns in the Sarfirouzabad plain. Unpublished MA thesis. Department of Archaeology. University of Tehran. Tehran.

Pullar J. 1990. Tepe Abdul Hosain: a Neolithic Site in Western Iran. Excavations 1978. BAR IS 563. Archaeopress. Oxford.

Smith P. E. L. 1976. Reflections on four seasons of excavations at Tapeh Ganj Dareh. In F. Bagherzadeh (ed.), Proceedings of the IVth Annual Symposium on Archaeological Research in Iran. Iranian Centre for Archaeological Research, Tehran: 11-22.

1990. Architectural Innovation and Experimentation at Ganj Dareh, Iran. World Archaeology 21(3): 323-335.

Smith P. E. L, Mortensen P. 1980. Three new early Neolithic site in western Iran. Current anthropology 21(4): 511-512.

Smith P. E. L., Young T. C. 1983. The Force of number: Population pressure in the central western Zagros. In T. C. Young, P. E. L. Smith and P. Mortensen (eds.), The Hilly Flanks and Beyond: Essays on the Prehistory of Southwestern Asia Presented to R.J. Braidwood. Studies in Ancient Oriental Civilization 36. The Oriental Institute of The University of Chicago, Chicago: 141-162. 
Young T. C. Jr. 1966. Survey in Western Iran 1961. Journal of Near Eastern Studies 25: 228-239.

1975. An Archaeological Survey in Kangavar Valley. In F. Bagherzadeh (ed.), Proceedings of the IIIth Annual Symposium on Archaeological Research in Iran. Iranian Center for Archaeological Research, Tehran: 23-30.

1969. Excavation at Godin Tepe: First Progress Report. Occasional Papers 17, Art and Archaeology. Royal Ontario Museum. Toronto.
Wilkinson T. J. 2000. Regional Approaches to Mesopotamian Archaeology: The Contribution of Archaeological Surveys. Journal of Archaeological Research 8(3): 219267.

Zeder M. A. 2005. A view from the Zagros: New Perspectives on livestock domestication in the Fertile crescent. In J.-D. Vigne, J. Peters and D. Helmer (eds.), First steps of animal domestication. New Archaeozoological Approaches. Oxbow Books, Oxford: 125-146. 